\title{
BERBAGAI ALTERNATIF BAHAN BAKU LOKAL UNTUK PAKAN IKAN
}

\author{
Sukarman \\ Balai Riset Budidaya Ikan Hias \\ Jl. Perikanan No. 13 Pancoran Mas, Depok \\ E-mail:carman_gbg@yahoo.com
}

\begin{abstract}
ABSTRAK
Sebagian besar bahan baku pakan ikan merupakan barang impor, sehingga harga pakan yang dihasilkan menjadi mahal. Perlu dicari alternatif bahan baku lokal yang bisa dipakai untuk pakan ikan dan udang. Tujuan makalah ini adalah membahas beberapa bahan baku alternatif lokal, nilai nutrisi dan rekomendasi penggunaannya dalam pakan ikan dan udang. Hasil studi literatur menunjukkan bahwa limbah industri mie instan, tepung daun singkong, homini, limbah roti, tepung rebon, dan MBM bisa dimanfaatkan sebagai bahan pakan alternatif untuk ikan dan udang. Bahan lainnya juga memungkinkan dimanfaatkan sebagai bahan baku pakan ikan asal diketahui aspek-aspek nutrisi baik proksimat, asam amino, vitamin, mineral, kecernaan dan anti nutrisinya, serta telah dilakukan uji coba pada ikan.
\end{abstract}

KATA KUNCI: bahan baku, pakan, alternatif, nutrisi, ikan

\section{PENDAHULUAN}

Salah satu faktor penting dalam budidaya ikan adalah ketersediaan pakan. Saat ini harga pakan buatan relatif mahal, karena sebagian besar menggunakan bahan baku impor. Usaha untuk menurunkan biaya pakan dapat dilakukan dengan cara membuat pakan sendiri menggunakan bahan baku lokal. Jenis bahan baku lokal di Indonesia sangat beragam, namun informasi mengenai nilai nutrisi, anti nurisi, ketersediaan, dan rekomendasi penggunaan dalam pakan ikan masih sedikit. Perhitungan nilai nutrisi dan tingkat penggunaan yang tidak tepat dalam pakan bisa menurunkan kualitas pakan yang akhirnya juga menurunkan performa ikan. Pengetahuan tentang beberapa bahan baku alternatif lokal yang bisa digunakan untuk pakan ikan dibahas dalam tulisan ini.

\section{BEBERAPA ALTERNATIF BAHAN BAKU PAKAN}

\section{Limbah Industri Mie Instan}

Perkembangan industri mie instan seperti mengikuti pertumbuhan penduduk, namun masih sangat sedikit informasi mengenai hal tersebut. Saat ini mie instan adalah makanan yang dianggap paling murah dan mudah untuk dikonsumsi. Mie instan sudah ada hampir di semua supermarket, minimarket bahkan warung-warung di pedesaan. Market dan industri mie instan di Indonesia berkembang sangat pesat. Industri mie instan banyak memanfaatkan terigu sebagai bahan baku utama, bahan lainnya seperti minyak sawit, tapioka, dan sagu porsinya sangat sedikit. Pada saat memproduksi mie instan terdapat potongan-potongan mie (mie reject) yang tidak boleh dijual untuk dikonsumsi manusia. Biasanya limbah industri mie dipakai oleh industri pakan ternak, terutama pakan ayam broiler. Sampai saat ini industri pakan ikan dan petani ikan belum menggunakannya. Padahal kalau dilihat dari bahan baku yang digunakan sebagian besar merupakan bahan baku yang terjamin keamanannya, bahkan untuk manusia sekalipun.

Membahas limbah industri mie menjadi bahan pakan ikan, sama halnya dengan membahas kelayakan tepung terigu sebagai pakan ikan. Perbedaannya adalah limbah industri mie instan telah melalui proses pematangan sehingga pati di dalam bahan tersebut lebih mudah dicerna baik oleh hewan ataupun manusia. Komposisi nutrisi limbah industri mie instan tentu saja perlu dibandingkan dengan bahan-bahan yang akan disubstitusi, seperti terigu dan dedak padi.

Kandungan proksimat limbah industri mie instan menunjukkan kadar protein yang lebih rendah dibandingkan dengan terigu dan dedak padi, tetapi limbah industri mie ini instan memiliki beberapa keunggulan lain. Keunggulannya kandungan lemaknya lebih tinggi. Lemak merupakan sumber energi bagi ikan. Lemak dalam limbah industri mie biasanya berasal dari minyak kelapa 


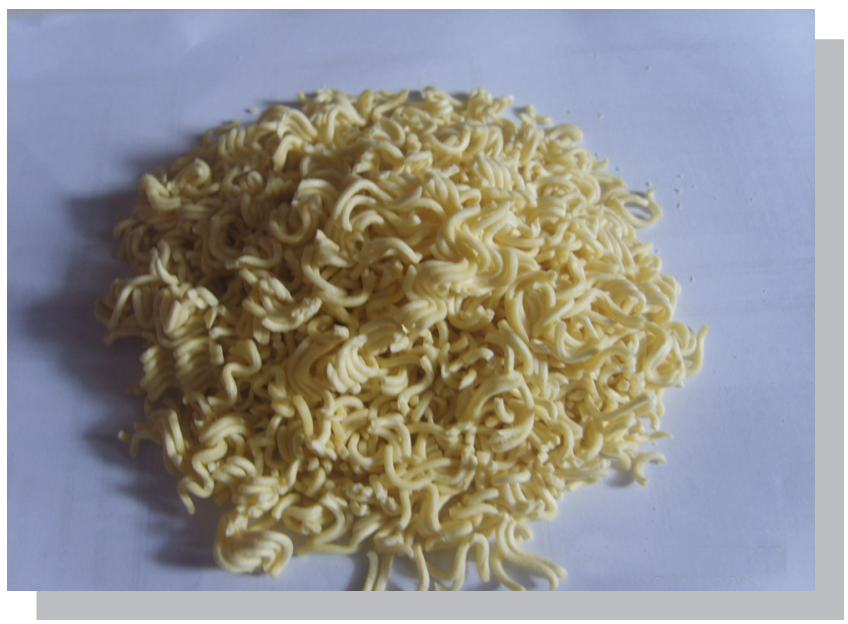

Gambar 1. Limbah industri mie instan

Tabel 1. Komposisi proksimat limbah industri mie instan (LIMI)

\begin{tabular}{lccc}
\hline \multicolumn{1}{c}{ Nutrien } & Terigu $^{1)}$ & LIMI & Dedak padi $^{2)}$ \\
\hline Kadar air (\%) & 12 & 10,3 & 11 \\
DE kcal/kg & 1.725 & 1.935 & 2.200 \\
Protein kasar (\%) & 14,3 & 8,57 & 12,9 \\
Lemak (\%) & 1,7 & 8,73 & 13,0 \\
Serat kasar (\%) & 1,1 & 1,37 & 11,4 \\
Kalsium (\%) & 0,04 & 0,13 & 0,04 \\
Fosfor (\%) & 0,02 & 0,24 & 0,6 \\
\hline
\end{tabular}

Sumber: ${ }^{1)}$ Hertrampf \& Pascual (2000); ${ }^{2)}$ NRC (1984)

sawit yang diduga mempunyai asam lemak bebas rendah, karena untuk konsumsi manusia. Keunggulan lain dibandingkan dedak padi adalah kandungan serat kasarnya lebih rendah. Serat kasar merupakan polimer monosakarida (Hemre et al., 2009); yang diketahui berpengaruh terhadap kecernaan karbohidrat. Semakin tinggi serat kasar diduga kecernaan karbohidrat akan semakin rendah. Kandungan asam fitat pada dedak padi juga menyebabkan beberapa nutrien seperti fosfor tidak dapat dicerna. Lemak pada dedak, walaupun jumlahnya tinggi merupakan asam-asam lemak tak jenuh. Telah diketahui bahwa asam lemak tak jenuh mudah sekali teroksidasi sehingga akan rusak dalam waktu yang relatif cepat.

Selain kandungan protein dan lemak, kandungan asamasam amino dari suatu bahan juga perlu dipertimbangkan. Ikan memerlukan kombinasi seimbang 20 jenis asam amino esensial dan non esensial utama penyusun protein (Schmittou et al., 1997). Kandungan asam amino limbah industri mie instan tidak jauh berbeda dengan asam amino dalam terigu, sehingga diharapkan dapat mensubstitusinya dalam pakan (Tabel 2 ).
Tabel 2. Kandungan asam amino limbah industri mie instan (LIMI)

\begin{tabular}{lcc}
\hline \multicolumn{1}{c}{ Asam amino } & Terigu & LIMI \\
\hline Arginin (\%) & 0,45 & 0,38 \\
Histidin (\%) & 0,27 & 0,22 \\
Isoleucin (\%) & 0,50 & 0,31 \\
Leucin (\%) & 0,94 & 0,68 \\
Lisin (\%) & 0,31 & 0,21 \\
Metionin (\%) & 0,20 & 0,14 \\
Phenil alanin (\%) & 0,64 & 0,39 \\
Treonin (\%) & 0,35 & 0,26 \\
Tryptophan (\%) & 0,12 & 0,09 \\
Valin (\%) & 0,53 & 0,40 \\
\hline
\end{tabular}

\section{Tepung Daun Singkong}

Singkong merupakan jenis tanaman umbi-umbian yang tersebar di banyak negara. Produksi singkong Indonesia menduduki peringkat ke-4 dunia setelah Nigeria, Thailand, dan Brazil yaitu mencapai 21 juta ton/tahun. Singkong sudah lama dimanfaatkan oleh manusia sebagai sumber karbohidrat, baik dikonsumsi langsung maupun diolah menjadi tapioka. Potensi singkong untuk dikembangkan menjadi sumber energi alternatif (ethanol) sangat tinggi, karena singkong banyak mengandung glukosa. Singkong juga sering kali digunakan sebagai bahan pakan ternak terutama sapi. Kandungan protein singkong sangat rendah, sehingga jarang sekali digunakan dalam pakan unggas dan ikan.

Kandungan protein yang bagus untuk unggas dan ikan justru terdapat pada daunnya. Hal tersebut masih kurang dimengerti oleh praktisi dan peneliti bidang pakan. Ketersediaan daun singkong tidak perlu diragukan dan tidak perlu diproduksi secara khusus. Produksi daun

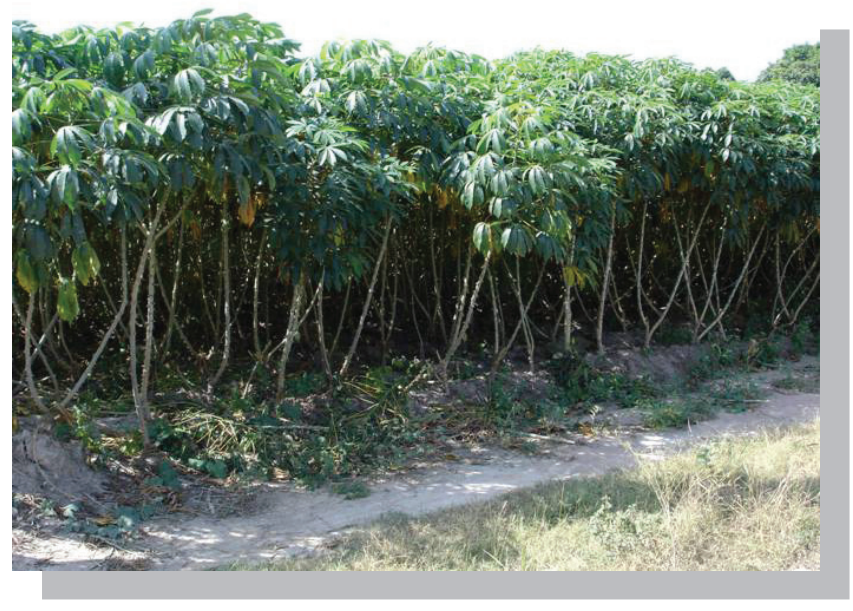

Gambar 2. Tanaman singkong 
singkong tercermin dari produksi singkong masingmasing daerah. Menurut Prihandana et al. (2007), provinsi penghasil singkong di Indonesia antara lain Lampung (24\%); Jawa Timur (20\%); Jawa Tengah (19\%); Jawa Barat (11\%); NTT $(4,5 \%)$; dan DIY $(4,2 \%)$.

Walaupun demikian tepung daun singkong harus diketahui secara pasti kandungan gizinya agar dapat dimanfaatkan sebagai bahan pakan ikan. Aspek anti nutrisi yang terdapat dalam daun singkong segar dan cara penanggulangannya juga perlu dipahami. Sehingga penggunaannya tidak membahayakan kesehatan ikan.

\section{Kandungan Protein dan Asam Amino}

Bahan baku dikategorikan sebagai sumber protein jika kandungan proteinnya lebih dari $18 \%$, sedangkan tepung daun singkong mengandung protein $27 \%$ sehingga bisa disebut sumber protein. Kandungan protein dan profil asam amino tepung daun singkong dibandingkan dengan bahan sumber protein lainnya terdapat pada Tabel 3.

Kandungan asam amino esensial tepung daun singkong terutama lisin $(2,00 \%)$ dan metionin $(0,40 \%)$ lebih rendah dibandingkan dengan tepung ikan $(5,02 \% ; 1,86 \%)$, bungkil kedelai $(2,76 \% ; 0,60 \%)$ tetapi lebih tinggi dibandingkan dengan DDGS $(0,74 \% ; 0,49 \%)$. Rasio asam amino lisin terhadap protein tepung daun singkong adalah $(7,4 \%)$ setara dengan nilai pada tepung ikan $(7,7 \%)$ dan lebih tinggi dari bungkil kedelai $(6,30 \%)$. Hal ini berarti bahwa pemanfaatan tepung daun singkong dalam formula mampu memenuhi kebutuhan asam amino tanpa harus meningkatkan kandungan protein pakan. Rasio antara

Tabel 3. Kandungan protein dan asam amino tepung daun singkong

\begin{tabular}{lcccc}
\hline Nutrien & $\begin{array}{c}\text { Tepung daun } \\
\text { singkong }\end{array}$ & DDGS & $\begin{array}{c}\text { Bungkil } \\
\text { kedelai }^{2}{ }^{2}\end{array}$ & $\begin{array}{c}\text { Tepung ikan } \\
\text { menhaden }^{2)}\end{array}$ \\
\hline Protein (\%) & 27 & 27,2 & 44 & 66,6 \\
Lisin (\%) & 2,00 & 0,74 & 2,76 & 5,02 \\
Metionin (\%) & 0,40 & 0,49 & 0,60 & 1,86 \\
Threonin (\%) & 3,01 & 1,01 & 2,16 & 2,66 \\
Tryptophan (\%) & 0,28 & 0,21 & 0,51 & 0,73 \\
Arginin (\%) & - & 1,06 & 3,05 & 4,06 \\
Iso leusin (\%) & 1,48 & 1,01 & 2,20 & 2,86 \\
Leucin (\%) & 2,86 & 3,18 & 3,31 & 4,66 \\
Valin (\%) & 1,39 & 1,34 & 2,07 & 3,39 \\
Phenil alanin (\%) & 1,15 & 1,32 & 2,21 & 2,59 \\
Histidin (\%) & 0,70 & 0,68 & 1,05 & 1,66 \\
\hline
\end{tabular}

DDGS adalah limbah pengolahan jagung menjadi etanol. Sumber: US Grain Council, ${ }^{1)}$ Amrulloh (2002); ${ }^{2)}$ Modifikasi dari Hertrampf \& Pascual (2000) asam amino dalam tepung daun singkong juga relatif seimbang.

\section{Kandungan Energi}

Energi bukan merupakan salah satu dari nutrien, tetapi energi adalah kalor (panas) yang dihasilkan dari metabolisme karbohidrat, lemak, dan protein. Untuk kebutuhan energinya ikan budidaya menggunakan protein dan lemak sebagai sumber utama dan karbohidrat sebagai sumber sekunder. Informasi yang tersedia tentang kandungan energi tepung daun singkong relatif masih sangat kurang. Namun demikian hal tersebut dapat diprediksi dari kandungan proksimat tepung daun singkong (Tabel 4).

Tabel 4. Komposisi proksimat tepung daun singkong

\begin{tabular}{lc}
\hline \multicolumn{1}{c}{ Nutrien } & Kandungan \\
\hline Protein kasar (\%) & 27 \\
Lemak (\%) & 7 \\
Serat kasar (\%) & 17,7 \\
Kalsium (\%) & 1,35 \\
Fosfor (\%) & 0,32 \\
\hline
\end{tabular}

\section{Kandungan Vitamin dan Mineral}

Menurut Katsir (2002), kandungan Fe, Mn, Zn, Niacin, Riboflavin, dan aktivitas vitamin A dalam tepung daun singkong berturut-turut adalah $467 \mathrm{mg} / \mathrm{kg} ; 115 \mathrm{mg} / \mathrm{kg}$; $7,87 \mathrm{~g} / \mathrm{kg} ; 43 \mathrm{mg} / \mathrm{kg} ; 67,2 \mathrm{mg} / \mathrm{kg} ; 10,7 \mathrm{mg} / \mathrm{kg}$; dan $2.000 \mathrm{x}$ $10^{3} \mathrm{IU} / \mathrm{kg}$.

\section{Kandungan Anti Nutrisi}

Faktor anti nutrisi pada singkong dan tepung daun singkong adalah kandungan HCN yang diperoleh dari Amyglandin, Dhurrin, dan Linamarin (Cheeke, 1992). Cheeke (1992) menambahkan bahwa kandungan HCN pada singkong dan daun singkong berturut-turut adalah $53 \mathrm{mg} / 100 \mathrm{~g}$ dan $104 \mathrm{mg} / 100 \mathrm{~g}$. Namun demikian tidak semua jenis singkong mempunyai kandungan $\mathrm{HCN}$ yang tinggi. Beberapa tanaman singkong (varietas tertentu) mempunyai kandungan $\mathrm{HCN}$ rendah dan dapat dikonsumsi langsung untuk manusia, ternak maupun ikan tanpa menimbulkan efek samping. Tepung daun singkong untuk pakan ternak dan ikan tidak dipilih dari varietas manapun, sehingga diperlukan proses untuk meminimalkan atau menghilangkan kandungan $\mathrm{HCN}$.

Golez (2002) menjelaskan bahwa daun singkong jika direndam selama 12-16 jam atau dipucatkan dengan air mendidih akan menghilangkan HCN dan menghasilkan 
tepung daun singkong yang aman untuk ikan. Cheeke (1992) berpendapat bahwa perendaman daun singkong akan mengaktifkan konversi cyanogenic glycoside menjadi HCN, dan jika dibilas dengan air akan menghilangkan kandungan HCN-nya. Cara lain adalah dengan memasak dengan air pada suhu yang stabil agar enzim menjadi rusak, sehingga tidak akan terbentuk HCN. Prinsip menghilangkan anti nutrisi pada daun singkong dengan melarutkan dalam air atau memanaskan bisa dimodifikasi. Salah satu caranya adalah dengan pengeringan di bawah sinar matahari. Metode ini lebih ekonomis dan cocok dilakukan di Indonesia, walaupun akan mengalami kesulitan jika singkong dipanen pada musim penghujan. Fasuyi (2005) melakukan berbagai percobaan untuk mengurangi anti nutrisi pada daun singkong. Hasil percobaannya menunjukkan bahwa pengeringan dengan sinar matahari 2-3 hari dan pencabikan dapat mengurangi tingkat $\mathrm{HCN}$ pada tingkat yang tidak berbahaya.

Secara umum kandungan nutrisi tepung daun singkong juga tergantung pada umur tanaman. Menurut Webeto et al. (2006), Kandungan protein, Fe, karoten, dan fosfor tepung daun singkong lebih tinggi pada umur 12 bulan dibandingkan umur 17 bulan. Sedangkan pada umur 17 bulan kandungan vitamin C, Zn, dan kalsium meningkat.

\section{Rekomendasi Penggunaan}

Umumnya daun singkong dikonsumsi oleh manusia (muda) dan sebagian besar diberikan pada ternak ruminansia dalam kondisi segar. Penggunaan pada ternak unggas dan ikan memang masih sangat jarang. Beberapa petani sering memberikan daun singkong ke dalam kolam bersama daun sente untuk ikan-ikan herbivora, namun masih sedikit sekali informasi ilmiah tentang hal tersebut. Menurut Ng \& Wee (1989), tepung daun singkong dapat menggantikan protein dari tepung ikan sampai dengan 20\% dalam pakan ikan nila (Oreochromis niloticus) tanpa mengurangi performan yang nyata.

\section{Homini (Limbah Produksi Gula dari Jagung)}

Tepung jagung merupakan bahan baku sumber energi tetapi rendah protein. Hal tersebut menjadikan jagung sebagai bahan baku utama pada ternak, dengan mempertimbangkan tingkat kesukaan ternak (Hertrampf \& Pascual, 2000). Penggunaan jagung pada ikan relatif sedikit, karena ikan lebih banyak memanfaatkan protein dan lemak sebagai sumber energi dibandingkan dengan pati (Schmittou et al., 1997). Energi jagung mentah kirakira $95 \%$ tercerna olah babi, tetapi hanya $26 \%$ dan $45 \%$ tercerna oleh ikan lele dan ikan nila. Hertrampf \& Pascual
(2000) menjelaskan bahwa pemanfaatan jagung oleh hewan dapat diperbaiki dengan perlakuan pemanasan. Selaras dengan hal tersebut Schmittou et al. (1997) menjelaskan bahwa perebusan jagung mampu meningkatkan kecernaannya pada ikan lele dan nila berturut-turut sekitar $58 \%$ dan $72 \%$. Penggunaan jagung pada ikan salmon juga mampu meningkatkan kecernaan dan pertumbuhan. Jagung memang bisa dan baik untuk dimanfaatkan sebagai bahan baku pakan ikan, tetapi industri pengolahan jagung saat ini berkembang sangat pesat sehingga harga jagung juga semakin meningkat. Industri pengolahan jagung, baik pengolahan basah maupun pengolahan kering menghasilkan limbah yang perlu dikaji kelayakannya sebagai bahan baku pakan ternak dan ikan. Beberapa hasil samping industri pengolahan jagung antara lain DDGS, homini, dedak jagung, dan germ. DDGS dapat dimanfaatkan sebagai sumber protein untuk ikan, karena kandungan proteinnya rata-rata lebih dari $27 \%$. Sedangkan homini dan dedak jagung bersifat seperti dedak dari sumber karbohidrat lainnya. Kemungkinan nilai nutrisi dan kecernaannya tidak jauh berbeda dengan dedak padi.

Homini atau homini feed adalah campuran dedak jagung, germs jagung dan sebagian pati jagung kuning, jagung putih atau biji-bijian shorgum dari hasil industri pearl homini, homini grits, atau table meal (Anonimous, 2005). Hal ini bisa disebutkan pula bahwa homini feed merupakan hasil penggilingan jagung secara kering. Menurut Tangendjaja \& Wina (2007), industri penggilingan jagung di Indonesia mempunyai kapasitas 1.000-3.000 ton/bulan.

\section{Aspek Nutrisi}

Homini mempunyai kandungan protein lebih tinggi dibandingkan dengan jagung tetapi lebih rendah dibandingkan dedak jagung (Hertrampf \& Pascual, 2000). Menurut Tangendjaja \& Wina (2007), kandungan asam amino homini lebih tinggi dibandingkan dengan jagung, tetapi menurut (Hertrampf \& Pascual, 2000), profil asam

Tabel 5. Komposisi proksimat homini

\begin{tabular}{|c|c|c|c|c|c|}
\hline Nutrien & Jagung ${ }^{1)}$ & Homini $^{1)}$ & Homini $^{2)}$ & Homini $^{3)}$ & $\begin{array}{c}\text { Dedak } \\
\text { padi }^{1)}\end{array}$ \\
\hline Kadar air (\%) & 11 & 10 & 9,9 & - & 11 \\
\hline Protein kasar $(\%)$ & 8,5 & 10,4 & 8,9 & $9-11,5$ & 12,9 \\
\hline Lemak (\%) & 3,8 & 8,0 & 5,4 & $2,0-9,0$ & 13,0 \\
\hline Serat kasar $(\%)$ & 2,2 & 5 & 4,5 & $3,0-6,0$ & 11,4 \\
\hline Abu (\%) & - & - & 5 & - & $11-15$ \\
\hline
\end{tabular}

Sumber: ${ }^{1)}$ NRC (1984); ${ }^{2)}$ Hertrampf \& Pascual (2000); ${ }^{3)}$ Anonimous (2005) 
amino homini sama dengan jagung. Kandungan serat kasar homini lebih tinggi dibandingkan jagung, tetapi lebih rendah dibandingkan dengan dedak padi. Serat kasar sangat mempengaruhi kecernaan bahan, sehingga diduga lebih cocok diberikan pada ikan herbivora dibandingkan karnivora.

Penggunaan homini diduga tidak sebaik penggunaan jagung dalam pakan ikan, hal ini erat hubungannya dengan serat kasar. Namun demikian jika dibandingkan dengan kandungan serat kasar dedak padi, serat kasar pada homini masih lebih rendah. Dari hal ini bisa diduga bahwa homini dapat dipakai untuk mensubtitusi dedak padi dalam pakan ikan. Komposisi asam amino homini dapat dilihat pada Tabel 6.

Tabel 6. Komposisi asam amino homini (g/16 g N)

\begin{tabular}{lcc}
\hline Asam amino & Homini & Dedak padi \\
\hline Arginin (\%) & 0,5 & 0,9 \\
Histidin (\%) & 0,2 & 0,3 \\
Isoleucin (\%) & 0,4 & 0,5 \\
Leucin (\%) & 0,9 & 0,9 \\
Lisin (\%) & 0,4 & 0,6 \\
Metionin (\%) & 0,2 & 0,3 \\
Phenil alanin (\%) & 0,4 & 0,5 \\
Treonin (\%) & 0,4 & 0,5 \\
Tryptophan (\%) & 0,1 & 0,1 \\
Valin (\%) & 0,6 & 0,7 \\
\hline
\end{tabular}

Persentase asam amino terhadap protein

Asam amino yang biasanya kurang di dalam bahan baku pada saat diformulasikan adalah lisin dan metionin. Berbeda dengan ternak, kebutuhan lisin ikan sepenuhnya harus dipenuhi dari bahan baku. Pemberian lisin sintesis sampai saat ini tidak diketahui jelas apakah efektif atau tidak. Nilai lisin pada homini tidak jauh berbeda dengan dedak padi, dengan perbedaan serat kasar yang cukup tinggi ada kemungkinan kecernaan lisin pada homini dan dedak padi setara untuk ikan. Sedangkan metionin merupakan salah satu asam amino bersulfur dan sering disebut sebagai donor methyl. Donor methyl lainnya adalah cystin, cholin, dan betain. Nutrien-nutrien tersebut sangat berkaitan dalam sistem metabolisme tubuh. Penambahan DL-Methionin untuk menutupi kekurangan dari bahan baku cukup efisien. Sedangkan L-methionin tidak diproduksi untuk pakan ternak maupun ikan.

Selain asam amino homini juga mengandung mineral dan vitamin. Kandungan mineral dalam bahan baku berasal dari jagung tergantung pada jenis jagung dan asal daerah penanamannya. Kandungan kalsium, fosfor, magnesium, dan potasium homini berturut-turut adalah $0,1 \% ; 6 \% ; 0,6 \%$; dan $0,3 \%$. Sedangkan kandungan kalsium dan fosfor dedak padi berturut-turut adalah $0,04 \%-0,3 \% ; 0,6 \%-1,6 \%$. Kandungan vitamin jagung sama halnya dengan vitamin pada bahan baku lainnya, seringkali tidak stabil. Hertrampf \& Pascual (2000), menyebutkan bahwa kandungan vitamin A pada homini bisa mencapai $400 \mathrm{IU} / \mathrm{kg}$, biotin 130 $\mathrm{mcg} / \mathrm{kg}$, dan cholin $1.030 \mathrm{mg} / \mathrm{kg}$. Kandungan mineral bahan baku selalu dicantumkan dalam sistem formulasi, karena mineral tidak rusak selama proses dan penyimpanan. Vitamin dalam bahan baku biasanya diabaikan nilainya, kecuali setiap bahan baku yang masuk dianalisis. Salah satu sifat vitamin dalam bahan baku adalah tidak stabil, sehingga seringkali vitamin rusak karena panas atau terlalu lama disimpan.

\section{Aspek Anti Nutrisi}

Faktor anti nutrisi pada bahan baku asal tanaman sering kali menjadi batasan penggunaannya untuk ternak maupun ikan. Anti nutrisi dalam bahan baku mempunyai sifat yang sangat spesifik, tergantung pada jenisnya. Misalnya, anti proteonase (trypsin inhibitor) pada kedelai akan hilang jika bahan tersebut dipanaskan pada suhu tertentu. Asam fitat pada sebagian besar bahan baku asal tanaman bisa diatasi dengan penambahan enzim fitase.

Homini merupakan hasil turunan dari pengolahan jagung, jadi sifat anti nutrisinya sama dengan jagung. Salah satu anti nutrisi yang terdapat pada jagung adalah serat kasar. Serat kasar merupakan polimer monosakarida (Hemre et al., 2009). Hanya sedikit informasi yang diketahui tentang efek dari tingginya serat kasar. Anti nutrisi yang lainnya adalah kemungkinan adanya mycotoxin. Mycotoxin dihasilkan oleh beberapa jamur. Tingkat mycotoxin pada jagung sangat beragam, tergantung teknologi pasca panen dan penyimpanannya.

\section{Limbah Roti}

Limbah roti atau tepung roti sangat bervariasi, tergantung pada bahan dan filer yang ditambahkan. Keragaman variasi nilai nutrisi yang paling tinggi adalah pada serat, lemak, dan kandungan garamnya. Keragaman ini mengharuskan pengguna tepung roti dalam pakan ikan untuk selalu mengecek beberapa nilai nutrisi ke laboratorium secara berkala terutama nilai serat kasar, garam, dan abu. Kandungan abu dan serat yang terlalu tinggi biasanya akan berpengaruh terhadap nilai energi untuk ikan. Sedangkan tingginya garam akan menyebabkan tingkat kecernaan bahan menurun. Keragaman inilah yang menyulitkan rekomendasi berapa 
tingkat tepung roti bisa digunakan dalam pakan ikan jika tidak dianalisis terlebih dahulu.

Kandungan protein, lemak, serat kasar, lisin, dan methionin dalam tepung roti berturut-turut adalah $10,6 \%$; $9,8 \% ; 2,4 \% ; 0,3 \%$; dan $0,2 \%$. Walaupun kandungan proksimat tepung roti rendah, nilai energinya lebih tinggi karena karena telah mengalami proses pemasakan. Penggunaan 5\%-10\% dalam pakan ikan bisa dilakukan dengan memperhitungkan total natrium dalam pakan.

\section{Tepung Rebon}

Rebon atau dalam bahasa internasional disebut krill berasal dari Euphausia sp., telah lama digunakan sebagai bahan baku pakan ikan dan udang. Tepung rebon kaya akan protein, pigmen, dan fosfolipid. Komposisi asam amino tepung rebon menyerupai tepung ikan.

Tabel 7. Komposisi kimia tepung rebon ${ }^{1)}$

\begin{tabular}{lccc}
\hline & Satuan & Rataan & Kisaran \\
\hline Bahan kering & $\%$ & 92,0 & $90,8-94,0$ \\
Protein kasar & $\%$ & 58,8 & $52,2-67,3$ \\
Lemak & $\%$ & 9,2 & $4,2-15,6$ \\
Abu & $\%$ & 13,6 & $9,7-15,9$ \\
Serat kasar & $\%$ & 6,4 & $5,3-8,4$ \\
Karotenoid $^{2)}$ & $\mathrm{mg} / \mathrm{kg}$ & 225 & $130-330$ \\
Flouride & $\mathrm{mg} / \mathrm{kg}$ & 2.247 & $2.000-2.700$ \\
\hline
\end{tabular}

Sumber: ${ }^{1)}$ Hertrampf \& Pascual (2000); ${ }^{2}$ Sebagian besar karotenoid dalam rebon berbentuk astaxanthin

Kandungan karotenoid yang cukup tinggi memberikan nilai tambah tepung rebon sebagai bahan baku ikan hias, udang, dan ikan salmon. Pengaruh karotenoid tepung rebon terhadap ikan tergantung pada tingkat pemberian, lamanya program pemberian, dan umur ikan sendiri.

Kandungan lemak tepung rebon tidak terlalu tinggi, tetapi merupakan sumber asam lemak yang baik. Kandungan fosfolipid tepung rebon berkisar antara 16,1\%$29,2 \%$ dan triglyserida berkisar antara 26,0\%-56\%. Kandungan fosfolipid dan karotenoid bisa digunakan untuk meningkatkan kualitas telur ikan.

Pembatasan minimal protein pada pakan ikan sudah dilakukan sejak puluhan tahun yang lalu, namun saat ini telah diketahui bahwa ikan tidak menyerap protein secara langsung. Protein bahan akan dipecah menjadi asam-asam amino dan kemudian dibentuk kembali menjadi protein jaringan sesuai genetik masing-masing ikan. Sehubungan dengan hal tersebut tepung rebon merupakan sumber
Tabel 8. Kandungan asam amino tepung rebon (krill meal) dibandingkan dengan tepung ikan

\begin{tabular}{lcc}
\hline \multicolumn{1}{c}{ Asam amino } & Tepung ikan & $\begin{array}{c}\text { Krill meal /tepung } \\
\text { rebon impor }\end{array}$ \\
\hline Protein (\%) & 66,6 & 58,8 \\
Lisin (\%) & 5,02 & 4,11 \\
Metionin (\%) & 1,86 & 1,74 \\
Threonin (\%) & 2,66 & 2,49 \\
Tryptophan (\%) & 0,73 & 0,52 \\
Arginin (\%) & 4,06 & 3,42 \\
Iso Leusin (\%) & 2,86 & 2,78 \\
Leucin (\%) & 4,66 & 4,35 \\
Valin (\%) & 3,39 & 2,78 \\
Phenil alanin (\%) & 2,59 & 2,49 \\
Histidin (\%) & 1,66 & 1,21 \\
\hline
\end{tabular}

asam amino yang cukup baik dan setara dengan tepung ikan. Namun tepung rebon impor (krill meal) tidak ekonomis dijadikan sumber protein utama, karena harganya relatif lebih mahal dibandingkan tepung ikan. Sedangkan tepung rebon lokal belum banyak digunakan oleh industri pakan sehingga harganya bisa relatif murah dan berpotensi sebagai bahan sumber protein.

Penggunaan tepung rebon dilaporkan mampu meningkatkan performan ikan salmon, namun demikian tingkat pemakaiannya perlu dibatasi karena tingginya kandungan flouride. Flouride dalam tepung rebon akan tersimpan pada jaringan ikan dan membahayakan kesehatan konsumen. Secara keseluruhan tepung rebon impor bisa menggantikan 40\%-60\% protein hewani pada pakan ikan dan $10 \%-20 \%$ protein hewani pada pakan udang (Hertrampf \& Pascual, 2000).

\section{Tepung Daging dan Tulang}

Salah satu bahan baku sumber protein yang murah adalah tepung daging dan tulang. Praktisi pakan lebih mengenal tepung daging dan tulang dalam bahasa inggris yaitu meat and bone meal (MBM). Bahan tersebut merupakan sumber protein yang murah untuk ternak dan ikan. Titik kritis bahan baku asal Australia dan Amerika ini ada pada lemak dan abu, besarnya partikel dan kecernaan oleh pepsinnya. Tidak semua pabrik pakan ikan di Indonesia menggunakan MBM, padahal MBM bisa digunakan dalam pakan ikan dengan kisaran 5\%-15\%, artinya bisa menggantikan sebagian dari tepung ikan. Nilai protein MBM umumnya berkisar antara $46 \%-48 \%$, dan kecernaan oleh pepsin (pepsin digestable $0,02 \%$ ) minimal $80 \%$. 
Kandungan fosfor pada tepung daging dan tulang cukup tinggi yaitu berkisar antara 2,5\%-7,0\% dengan nilai kecernaan $22 \%-44 \%$ dari fosfor total. Nilai tersebut setara dengan fosfor total pada tepung ikan yaitu antara $1,1 \%$ $4,2 \%$. Namun demikian MBM tidak bisa menggantikan tepung ikan dalam pakan secara keseluruhan. Hal tersebut karena pertimbangan palatabilitas dan kualitas lemaknya.

\section{KESIMPULAN}

Bahan apapun bisa dimanfaatkan sebagai bahan pakan ikan dan udang dengan syarat telah diketahui aspek-aspek nutrisinya (proksimat, asam amino, dan tingkat kecernaan) dan aspek anti nutrisinya ( $\mathrm{HCN}$, flouride, dan lain sebagainya).

\section{DAFTAR ACUAN}

Anonimous. 1984. Nutrient Requirement of Fish. National Research Council. USA, 155 p.

Anonimous. 2005. CJ Feed Ingredient Manual. (Unpublished), $469 \mathrm{p}$.

Anonimous. 2006. Nutrient Content of DDGS : Variability and Measurement. A Guide to Distiller's Dried Grains with Soluble (DDGS). DDGS User Handbook. U.S. Grains Council, pp 1-17.

Amrulloh, I.K. 2002. Nutrisi Ayam Broiler. Lembaga Satu Gunungbudi, 264 p.

Cheeke, P.R. 1992. Natural Toxicants in Feed, Forages, and Poisonous Plant. Interstate Publishers, Inch. Danville, Illionis, 479 p.

Fasuyi, A.O. 2005. Nutrient Composition and Processing Effects on Cassava Leaf (Manihot esculenta, Crantz) Antinutrients. Pakistan J. of Nutrition, 4(1): 37-42.
Golez, V.N. 2002. Processing of Feedstuffs and Aquafeed. Nutrition in Tropical Aquaculture, 5: 125-147.

Hertrampf, J.W \& Pascual, F.P. 2000. Hand Book on Ingredient for Aquaculture Feed. Kluwer Academic Publishers, $573 \mathrm{p}$.

Hemre, G-I., Amlund, H., Aursand, M., Bakke, A.M., Olsen, R.E., RingØ, E., \& Svihus, B. 2009. Criteria for safe use of plant ingredients in diets for aquacultured fish. Norwegian Scientific Committee for Food Safety, Vitenskapskomiteen for mattrygghet (VKM), pp 31.

Ng. W.K. \& Wee, K.L. 1989. The nutritive value of cassava leaf meal in pelleted feed for Nile tilapia. Aquaculture, 83: 45-58.

Prihandana, R., Noerwijari, K., Andinurani, P.G., Styaningsih, D., Setiadi, S., \& Hendroko, R. 2007. Bioetanol Ubi Kayu, Bahan Bakar Masa Depan. Agromedia Pustaka. 194 hlm.

Schmittou, H.R, Chremer, M.C. \& Zhang, J. 1997. Principle and Practice of High Density Fish Culture in Low Volume Cages. (Copyright 2004 American Soybean Meal Assosiation). $87 \mathrm{p}$.

Tangendjaja \& Wina. 2007. Limbah Tanaman dan Produk Samping Industri Jagung untuk Pakan. Balai Penelitian Ternak, Bogor, Hal : 430-445.

Webeto et al. 2006. Nutrient in the Cassava (manihot esculenta crant) Leaf Meal at Three Ages of Plant. Ciênc. Tecnol. Aliment. Campinas, 26(4): 865-869. 